Terakreditasi

Ditjen Penguatan Riset dan Pengembangan, Kemenristekdikti

Keputusan No: 21/E/KPT/2018, Tanggal 9 Juli 2018
Mei 2019, 6(2):214-224

DOI: http://dx.doi.org/10.33772/jitro.v6i2.5638

http://ojs.uho.ac.id/index.php/peternakan-tropis

\title{
Review: Hidrogen Sianida dan Implikasinya pada Ternak
}

\author{
Yanuartono $^{1}$, Soedarmanto Indarjulianto ${ }^{1 *}$, Alfarisa Nururrozi ${ }^{1}$, Hary Purnamaningsih ${ }^{1}$ \\ ${ }^{1}$ Fakultas Kedokteran Hewan Universitas Gadjah Mada \\ Jl. Fauna No.2, Karangmalang, Depok, Sleman. 55281 Yogyakarta \\ *Email korespondensi: indarjulianto@ugm.ac.id
}

(Diterima: 19-02-2019; disetujui 18-04-2019)

\begin{abstract}
ABSTRAK
Sejumlah besar tanaman hijauan banyak mengandung glikosida sianogenik dandapat dirombak menjadi hidrogen sianida ( $\mathrm{HCN})$ yang bersifat toksik. Hidrogen sianida dapat menyebabkan keracunan pada manusia dan hewan.Konsentrasi HCN dalam hijauan dapat diturunkan melalui beberapa metode pengolahan seperti pengupasan, pengeringan, fermentasi, pemotongan dan penyimpanan.Gejala klinis keracunan $\mathrm{HCN}$ pada ruminansia dapat berupa peningkatan pulsus, sesak nafas, lemas, tremor, dilatasi pupil, kembung dan dapat menyebabkan kematian. Pengobatan dapat dilakukan dengan pemberian sodium nitrit dan sodium tiosulfat melalui injeksi intravena.
\end{abstract}

Kata Kunci : glikosida sianogenik, keracunan klinis, intravena

\begin{abstract}
A large number of forage contains cyanogenic glycosides which will be degraded into hydrogen cyanide $(\mathrm{HCN})$ which are toxic. Hydrogen cyanide can cause poisoning in both animals and humans. Hydrogen cyanide concentration in the forage can be reduced through several methods of feed processing. The processing includes stripping, drying, fermentation, soaking, chopping, and storing. Clinical symptoms of HCN poisoning in ruminants are increased pulse, difficulty of breathing, weakness, tremors, pupil dilatation, bloating, and can lead to death. Treatments can be performed by administering sodium nitrite and sodium thiosulfate by intravenous injection.
\end{abstract}

Keywords: cyanogenic glycosides, clinical poisoning, intravenous

\section{PENDAHULUAN}

Lebih dari 2600 spesies tanaman di bumi ini mengandung glikosida sianogenik yang tersebar merata pada jenis-jenis hijauan seperti rosaceae, leguminosae, gramineae dan Araceae (Enneking \& Wink, 2000; Zagrobelny et al., 2004). Glikosida sianogenik sendiri bersifat tidak toksik, tetapi proses hidrolisis oleh enzim yang terdapat dalam tanaman itu sendiri atau hewan yang mengonsumsi dapat menghasilkan sianida bersifat toksik atau HCN (Blood \& Radostits, 1989). Di Indonesia, banyak kasus kematian ternak akibat keracunan HCN karena rendahnya pengetahuan peternak terhadap anti nutrisi pada hijauan pakan. Salah satu contoh adalah kasus kematian 26 ekor kambing ettawa akibat keracunan HCN setelah mengonsumsi hijauan angrung (Trema orientalis) terjadi di Kalimantan Timur (Yuningsih, 2007). Konsentrasi HCN pada bahan pakan dapat diturunkan atau bahkan dihilangkan melalui beberapa metode pemrosesan pakan. Metode yang sering dipakai adalah pelayuan, pencacahan, pemanasan alami, perebusan, pengukusan, fermentasi dan pemanasan kering (Montagnac et al., 2009).

Ruminansia seperti sapi, domba, kambing lebih peka terhadap HCN dibandingkan dengan monogastrik seperti kuda dan babi (Sousa et al., 2003; Carlsson \& Anderson, 2013). Hal tersebut disebabkan karena mikroorganisme dalam rumen dengan cepat akan memecah sel-sel tanaman sehingga HCN yang bersifat toksik akan terlepas. Gejala klinis yang tampak pada ruminansia 
adalah peningkatan frekuensi napas, pulsus, dilatasi pupil mata, tremor serta membrana mukosa berwarna merah terang karena terjadi saturasi oksigen di hemoglobin. Anamnesa, pengenalan gejala klinis dan penanganan secara dini sangat menentukan keberhasilan terapi. Namun, dalam kasus keracunan yang berat biasanya hewan mati dalam waktu 30 sampai 45 menit setelah munculnya gejala klinis pertama. Pengobatan dapat dilakukan dengan pemberian sodium nitrit dan sodium tiosulfat melalui injeksi intravena (Stoltenow \& Lardy, 2012).

\section{HIDROGEN SIANIDA DALAM BAHAN PAKAN TERNAK}

Ribuan spesies tanaman, termasuk sejumlah besar tanaman pangan yang bernilai ekonomis tinggi memiliki kemampuan mensintesis glikosida sianogenik (Francisco \& Pinotti, 2000). Glikosida sianogenik juga terdistribusi secara luas diantara 100 famili tanaman berbunga, beberapa spesies pakis, jamur dan bakteri serta memiliki 25 macam glikosida sianogenik dengan kandungan yang bervariasi (Hlaing et al., 2011). Contoh glikosida sianogenik yang terkandung dalam tanaman adalah amigdalin, durin, linamarin, lotaustralin, prunasin, taksifilin, vicianin, linustatin, triglosinin, neolinustatin dan xerantin (Haque \& Bradbury, 2002; Simeonova \& Fishbein, 2004). Glikosida sianogenik adalah kelompok senyawa metabolit sekunder yang dapat menghasilkan HCN pada pemecahan enzimatik (Siritunga et al., 2004; Zagrobelny et al., 2004). Glikosida sianogenik banyak terdapat pada berbagai jenis hijauan seperti Rosaceae, Leguminosae, Gramineae dan Araceae (Enneking \& Wink, 2000). Namun demikian, menurut Poulton (1990), hanya sekitar 300 spesies tanaman yang telah teridentifikasi mengandung glikosida sianogenik. Glikosida sianogenik sendiri sebenarnya berfungsi sebagai pertahanan tumbuhan terhadap serangan herbivora, serangga, jamur dan bakteri (Moller, 2010). Setiap kejadian yang mengakibatkan pecah atau robeknya sel tanaman, akan menyebabkan senyawa sianogenik bergabung dengan enzim-enzim $\beta$-glucosidase dan $\alpha$-hydroxynitrile lyasese hingga menghasilkan HCN (Vetter, 2000; Agbor-Egbe \& Lape-Mbome, 2006). Pecahnya sel tanaman biasanya terjadi pada saat proses pengunyahan terutama pada ruminansia (Stoltenow \& Lardy, 2012).

Spesies tanaman yang bernilai ekonomis tinggi, terutama di negara berkembang, baik digunakan sebagai pakan ternak maupun bahan pangan manusia dan yang mengandung glikosida sianogenik tinggi adalah singkong (Andersen et al., 2000). Singkong merupakan tanaman yang sangat populer di negara-negara tropis termasuk Indonesia. Tanaman tersebut dimanfaatkan secara luas oleh penduduk, terutama umbi dan daunnya. Selain dikonsumsi manusia, produksi singkong yang melimpah serta limbahnya yang berupa kulit singkong biasanya dimanfaatkan sebagai pakan ternak. Namun demikian, singkong, baik umbi, kulit umbi maupun daun juga kaya sianida dalam bentuk sianogenik glukosida linamarin dan lotaustralin. Adanya senyawa tersebut menyebabkan pemakaian singkong secara luas untuk ternak menjadi terbatas (Oluremi \& Nwosu, 2002). Berdasarkan kandungan HCN, singkong dikelompokkan menjadi 3 kelompok. Kelompok pertama adalah sangat toksik, dengan kandungan asam sianida lebih dari $100 \mathrm{mg} / \mathrm{kg}$ dalam ampas singkong. Kelompok kedua adalah moderat, dengan kandungan asam sianida 50$100 \mathrm{mg} / \mathrm{kg}$ dalam ampas singkong. Sedangkan kelompok ketiga adalah ringan dengan kandungan asam sianida kurang dari $50 \mathrm{mg} / \mathrm{kg}$ dalam ampas singkong (Kobawila et al., 2005). Berdasarkan kadar HCN, Departemen Perindustrian (1999) menyatakan bahwa singkong dapat dibedakan menjadi empat kelompok, yaitu: (a) singkong manis, dengan kandungan asam sianida yang sangat rendah, hanya sebesar $0,04 \%$ atau $40 \mathrm{mg} / \mathrm{kg}$ singkong; (b) singkong agak beracun dengan kandungan HCN antara $0,05-0,08 \%$ atau $50-80 \mathrm{mg} / \mathrm{kg}$ singkong; (c) singkong beracun dengan kandungan $\mathrm{HCN}$ antara $0,08-0,10 \%$ atau $80-100 \mathrm{mg} / \mathrm{kg}$ singkong; dan (d) singkong sangat beracun, dengan kandungan $\mathrm{HCN}$ lebih dari $0,1 \%$ atau $100 \mathrm{mg} / \mathrm{kg}$ singkong. Menurut Kavana et al. (2005), kandungan $\mathrm{HCN}$ daun singkong cukup tinggi karena mencapai $289 \mathrm{mg} / \mathrm{kg}$ BK. Limbah kulit singkong dapat dimanfaatkan menjadi pakan ternak apabila dilihat dari jumlah ketersediaannya. Kendala penggunaan limbah kulit singkong adalah kandungan protein yang rendah, serat kasar serta $\mathrm{HCN}$ yang tinggi. Kandungan $\mathrm{HCN}$ 
dalam singkong tidak konstan karena dipengaruhi oleh faktor lingkungan (El-Sharkawy, 2004). Jika singkong mengalami musim kering yang panjang selama pertumbuhannya, kandungan $\mathrm{HCN}$ akan mengalami peningkatan. Disamping itu, unsur $\mathrm{N}$ yang terdapat di dalam pupuk kimia dapat meningkatkan kandungan HCN singkong. Ditambahkan pula oleh Cardoso et al. (2005) bahwa kandungan HCN dalam singkong dipengaruhi oleh varietas tanaman, genetik tanaman, umur tanaman, tingkat kematangan, dan kesuburan tanah.

Selain singkong, spesies tanaman dengan kandungan glikosida sianogenik yang tinggi adalah sorghum (Sorghum bicolor) (Oduguwa \& Fafiolu, 2004; Ganjewala et al., 2010). Sedangkan glikosida sianogenik yang umum ditemukan dalam tanaman bernilai ekonomis adalah durin (Sorghum spp.), linamarin (singkong, linseed meal), taksifilin (rebung/ bamboo shoots) dan amigdalin (buah almond, apel, persik dan apricot) (Simeonova \& Fishbein, 2004). Tanaman maupun limbah tanaman yang sering digunakan sebagai hijauan pakan ternak di Indonesia adalah kulit pisang (Musa paradisiaca), daun papaya (Carica papaya), daun nangka (Artocarpus Heterophyllus Lamk), gamal (Gliricidia sepium), lamtoro (Leucaena leucocephala), turi (Sesbania grandiflora), rumput gajah (Pennisetum purpureum) dan rumput raja (Pennisetum purpuphoides).

Sorghum (Sorghum bicolor) atau cantel adalah tanaman yang sangat ekonomis yang dapat tumbuh pada daerah yang kering dengan hasil yang tinggi (Anglani,1998). Sorgum merupakan salah satu komoditas potensial yang dapat dikembangkan mendukung program diversifikasi pangan di Indonesia. Sebagai pakan ternak, biji sorgum digunakan untuk bahan campuran pakan unggas, sedangkan batang dan daun banyak digunakan sebagai pakan ruminansia (Sirappa, 2003). Sorgum mengandung HCN bervariasi tergantung tingkat pertumbuhannya, dengan kandungan terbesar pada daun dan tangkai (Prasad \& Dhanya, 2011). Haque \& Bradbury (2002) menyatakan bahwa kandungan HCN dalam sorghum bervariasi antara $750-790 \mathrm{mg} / \mathrm{kg}$. Pandey et al. (2011) menunjukkan bahwa pemupukan dengan $\mathrm{N}$ akan meningkatkan kandungan $\mathrm{HCN}$ pada sorghum.
Jumlah produksi pisang di Indonesia pada tahun 2017 menurut data Badan Pusat Statistik mencapai 7.162.685 ton/tahun. Pada umumnya kulit pisang belum dimanfaatkan secara maksimal sebagai pakan ruminansia seperti kambing, sapi, dan kerbau dan hanya dibuang sebagai limbah organik. Anhwange (2008) melaporkan kandungan HCN dalam kulit pisang sekitar 1,33 $\mathrm{mg} / \mathrm{g}$. Tanaman pepaya (Carica papaya L.) merupakan tanaman yang banyak diteliti saat ini akan tetapi tampaknya daun pepaya hanya sedikit atau sama sekali tidak mengandung $\mathrm{HCN}$ (USDA, 2001). Sampai saat ini daun nangka (Artocarpus heterophyllus Lamk) merupakan pakan hijauan yang sangat disukai oleh kambing. Di Indonesia, daun nangka merupakan pakan utama untuk ruminansia kecil seperti kambing dan domba yang dipelihara secara intensif maupun semi intensif. Menurut Ersam (2001) dan Chandrika et al. (2006), anti nutrisi utama dalam daun nangka adalah saponin sedangkan sianogenik glukosida yang terkandung di dalamnya tidak banyak diketahui sehingga perlu dilakukan penelitian yang lebih mendalam.

Dari hasil penelitian-penelitian yang telah dilakukan tersebut kandungan glikosida sianogenik pada kulit pisang (Musa paradisiaca), daun pepaya (Carica papaya) dan daun nangka (Artocarpus heterophyllus Lamk) tampaknya rendah atau tidak ditemukan sama sekali. Dengan demikian pengolahan yang dikerjakan terutama adalah untuk menghilangkan faktor anti nutrisi selain $\mathrm{HCN}$ yang terkandung dalam ketiga bahan pakan tersebut diatas. Pengolahan bahan pakan tersebut diatas secara sederhana dapat dilakukan seperti pelayuan, penjemuran dan fermentasi untuk menghilangkan faktor anti nutrisi yang terkandung dalamnya.

Gamal atau Gliricidia sepium merupakan salah satu jenis tanaman leguminosa yang banyak disukai oleh ruminansia kecil seperti kambing dan domba. Kandungan HCN dalam daun Gliricidia sepium tergolong rendah, $4 \mathrm{mg} / \mathrm{kg}$, namun hal ini perlu juga dicermati karena dapat menganggu kesehatan ternak jika terkonsumsi dalam jumlah yang besar. Chanchay \& Poosaran (2009) melaporkan bahwa lamtoro (Leucaena leucocephala) memiliki nilai nutrisi yang cukup baik dan hampir sama dengan gamal dan mengandung $\mathrm{HCN}$ dalam kadar rendah. Antinutrisi yang paling banyak terkandung dalam 
lamtoro adalah mimosin, yang dapat menimbulkan keracunan serta gangguan kesehatan apabila dikonsumsi dalam jumlah yang berlebihan dan secara terus menerus dalam jangka waktu yang cukup lama (Adekojo et al., 2014).

Kandungan HCN pada rumput gajah (Pennisetum purpureum) tergantung dari musim, dimana kandungan pada saat musim hujan lebih tinggi dibandingkan dengan musim kemarau, meskipun tidak berbeda jauh. Rata-rata kandungan HCN pada rumput gajah adalah 1,58 $\mathrm{mg} / 100 \mathrm{~g}$ (Onyeonagu et al., 2013). Kandungan HCN pada rumput benggala (Panicum maximum) sangatlah rendah sehingga tidak mempengaruhi kesehatan ternak. Hasil penelitian Onyeonagu \& Ukwueze (2012) menunjukkan bahwa pemotongan rumput benggala dengan interval 9 minggu mampu menurunkan kandungan $\mathrm{HCN}$ secara signifikan. Tanaman berumur pendek seperti Glyceria maxima, Sudan grass yang tinggi tanamannya masih kurang dari $80 \mathrm{~cm}$ tidak dianjurkan untuk dikonsumsi ternak karena kandungan HCN cukup tinggi (Pickrell et al., 1991) tetapi kandungan tersebut akan menurun seiring dengan umur tanaman (Etuk et al., 2012; Simili et al., 2013).

\section{PENGARUH PEMROSESAN TERHADAP KANDUNGAN HIDROGEN SIANIDA}

Metode pemrosesan bahan pakan secara fisik dan kimia dilakukan untuk menurunkan atau menghilangkan faktor anti nutrisi seperti perendaman, pemasakan, perkecambahan, fermentasi, ekstraksi selektif, iradiasi dan perlakuan enzimatik. Pemrosesan diperlukan karena faktor anti nutrisi dapat menurunkan intake pakan dan kecernaan, defisiensi mineral, toksisitas, ketidakseimbangan gizi, dan mengganggu kesehatan hewan (Allen \& Segarra, 2001). Di Indonesia, sebagian besar kualitas hijauan pakan ruminansia sangat rendah, dimana pada umumnya diberikan hijauan kualitas rendah dan limbah pertanian. Upaya memanfaatkan bahan pakan dengan penerapan teknologi untuk meningkatkan kualitas nutrisi serta menurunkan faktor antinutrisi yang terkandung di dalamnya telah banyak dilakukan, namun kesadaran peternak untuk menerapkannya masih rendah.
Sebagai contoh, pelatihan teknologi pengolahan seperti fermentasi dan amoniasi telah mereka peroleh, akan tetapi pada kenyataan di lapangan masih belum banyak diterapkan oleh para peternak.

Penurunan konsentrasi HCN dalam bahan pakan dapat dilakukan dengan berbagai macam metode pemrosesan (Soetan, 2008). Metode pemrosesan tanaman singkong guna menurunkan kandungan HCN meliputi pengupasan, pengeringan, penjemuran, fermentasi, perendaman, pencacahan, dan penyimpanan (Sokerya et al., 2009). Pengupasan umbi singkong mampu menurunkan kandungan $\mathrm{HCN}$ sebesar 50\% (Agbor-Egbe \& Mbome, 2006). Lambri et al. (2013) menunjukan bahwa proses fermentasi singkong selama 24 jam mengakibatkan penurunan kandungan $\mathrm{HCN}$ sebesar $80 \%$. Hasil penelitian Kobawila et al. (2005) menunjukan bahwa fermentasi selama 48 jam dengan menggunakan bakteri Leuconostoc mesenteroides akan menurunkan kandungan $\mathrm{HCN}$ sebesar 70,67\%. Menurut hasil penelitian Achi \& Akomas (2006), HCN pada fermentasi kulit singkong terjadi karena adanya aktivitas enzim $\beta$ glukosidase yang dihasilkan oleh bakteri asam laktat terutama Leuconostoc mesenteroides. Tanaman singkong tersedia melimpah hanya pada saat panen, namun hanya sebagian kecil yang bisa dimanfaatkan sebagai pakan ternak. Daun singkong dapat diawetkan dengan cara dibuat silase sehingga dapat dimanfaatkan sebagai pakan ternak. Selain dapat mengawetkan, silase juga dapat mempertahankan atau bahkan meningkatkan nilai nutrisi dan menurunkan kandungan HCN dalam daun singkong. Bentuk silase daun singkong terbukti dapat menurunkan kadar $\mathrm{HCN}$ sebesar 60 sampai $70 \%$ serta dapat mempertahankan kondisi, kualitas nutrisi dan palatabilitasnya dalam waktu yang cukup lama (Kavana et al., 2005).

Pengolahan daun singkong untuk menurunkan kandungan HCN memerlukan waktu lebih cepat dibandingkan dengan umbi. Proses pelayuan daun singkong selama satu hari akan menurunkan kandungan $\mathrm{HCN}$ hampir sebesar 50\% (Yuningsih, 2012). Sedangkan penjemuran daunakan menurunkan kandungan HCN (bahan 
kering) dari $190 \mathrm{mg} / \mathrm{kg}$ daun segar menjadi 20 $\mathrm{mg} / \mathrm{kg}$ (Bui et al., 2000). Metode pelayuan yang dilanjutkan dengan penjemuran mampu menurunkan kandungan $\mathrm{HCN}$ sebesar 58\% (Hang \& Preston, 2005) dan 45\% (Phengvichith \& Ledin, 2007). Namun demikian, metode penjemuran tersebut memiliki kendala pada saat musim penghujan. Kelembaban yang tinggi dan kurangnya sinar matahari akan mengakibatkan hasil penjemuran memiliki kualitas nutrisi yang rendah (Apata \& Babalola, 2012). Rendahnya kualitas tersebut terutama disebabkan oleh kontaminasi aflatoksin dan Aspergillus. Menurut Kumar (2003), metode pemanenan yang dilanjutkan dengan pelayuan pada jenis leguminose juga akan menurunkan kandungan HCN. Kombinasi pencacahan dan penjemuran daun singkong sangat efektif untuk menurunkan kandungan HCN (Fasuyi, 2005). Kandungan $\mathrm{HCN}$ akan menurun $77 \%$ pada silase daun singkong sehingga dapat meningkatkan daya cerna pada babi (Borin et al., 2005).

Menurut Chaouali et al. (2013), rami/ flaxseed (L. usitatissimum) merupakan bahan pakan yang menarik karena kandungan asam linolenat dan serat yang tinggi, namun juga mengandung $\mathrm{HCN}$ yang cukup tinggi. Biji rami yang direbus pada temperatur $230^{\circ} \mathrm{C}$ selama 15 18 menit mampu menghilangkan 90-100\% HCN. Hasil penelitian Putra (2009) pada rebung menunjukkan bahwa proses pemasakan, baik dengan cara perebusan maupun pengukusan, dapat menurunkan kandungan asam sianida rebung bambu. Selanjutnya dinyatakan juga bahwa perendaman selama 12 jam sebelum dilakukan perebusan maupun pengukusan dapat menurunkankadar HCN rebung. Pemotongan dan pencucian dengan air mengalir menunjukan penurunan HCN yang signifikan padagadung (Dioscorea hispida Dennst.) (Kumoro et al., 2011). Metode perkecambahan pada Treculia africana selama 120 jam mampu menurunkan kandungan HCN secara signifikan (Ugwu \& Oranya, 2006). Pengeringan atau perendaman dalam air mampu menurunkan bahkan menghilangkan konsentrasi $\mathrm{HCN}$ pada daun dan biji sorghum (Leder, 2004). Sedangkan pembuatan hay atau silase mampu menurunkan konsentrasi HCN dalam tanaman sorghum (Sorghum spp), meskipun keracunan HCN akibat mengonsumsi tanaman sorghum pada ternak ruminansia sangat jarang terjadi.

Pada satu sisi metode pemrosesan bahan pakan memang bermanfaat untuk menurunkan kandungan anti nutrisi pada bahan tersebut, namun demikian pemrosesan tersebut juga menimbulkan dampak negatif pada kualitasnya. Dampak negatif tersebut berupa penurunan unsur nutrisi yang lain terutama vitamin-vitamin baik yang larut air maupun larut lemak atau beberapa mineral penting. Penggilingan bijian akan menurunkan kandungan tiamin, biotin, vitamin B6, asam folat, riboflavin, niasin, dan asam pantotenat serta mineral seperti $\mathrm{Ca}, \mathrm{Fe}$ dan $\mathrm{Mg}$ (Prodanov et al., 2004; Fardet, 2010). Dari sekian banyak metode tersebut di atas, tampaknya metode penjemuran atau pengeringan dengan sinar matahari merupakan metode paling sederhana, mudah dikerjakan dan dengan biaya yang paling rendah. Dengan demikian, yang lebih diperlukan peternak di lapangan adalah peningkatan pemahaman akan arti penting pemrosesan pakan yang dilanjutkan dengan penerapan, sehingga ternak dapat terlindungi dari akibat buruk adanya kandungan anti nutrisi dari setiap bahan pakan.

\section{GEJALA, DIAGNOSA DAN TERAPI KERACUNAN HCN}

Hidrogen sianida adalah senyawa kimia yang bersifat toksik dan merupakan jenis racun yang paling cepat aktif dalam tubuh sehingga dapat menyebabkan kematian dalam waktu 30 sampai 45 menit setelah munculnya gejala klinis. Pada kenyataannya, dosis mematikan dari glikosida sianogenik asal tanaman tidak dapat ditentukan dengan tepat karena jumlah glikosida sianogenik dari setiap tanaman yang terkonsumsi mungkin berbeda beda. Hal tersebut kemungkinan disebabkan oleh musim, cuaca, umur tanaman, bagian tanaman dan jumlah yang terkonsumsi ternak serta proses yang digunakan sebelum diberikan ke ternak. Pada hewan ternak, HCN sudah sejak lama dikaitkan dengan gejala gejala yang dapat mempengaruhi susunan syaraf 
pusat dan menimbulkan ataksia pada domba, sapi, dan kuda yang merumput (Yildiz et al., 2017). Ruminansia lebih peka terhadap keracunan HCN dibandingkan dengan monogastrik. Lambung monogastrik yang memiliki $\mathrm{pH}$ asam tidak memungkinkan linamarase untuk bekerja sehingga mengakibatkan pelepasan hidrogen sianida menjadi sangat lambat, sehingga eliminasi terjadi lebih cepat. Setelah mengalami hidrolisis dalam rumen, glikosida sianogenik melepaskan HCN yang mudah diabsorbsi masuk dalam sirkulasi secara cepat (Arnold et al.., 2014). Dalam plasma, HCN terdisosiasi menjadi ion nitrile ( $\mathrm{CN}-)$ dan hidrogen. Ion nitrile $(\mathrm{CN}-)$ akan berikatan kuat ke terminal sitokrom dari rantai pernapasan mitokondria, sehingga menghambat jaringan respirasi sel dan mengakibatkan anoksia. Kematian terjadi karena depresi dari sistem saraf pusat (SSP), setelah penghambatan aktivitas sitokrom oksidase otak (McKenzie, 2002).

Kejadian perakut menunjukan gejala klinis setelah 10-15 menit hewan mengonsumsi pakan beracun dan mati 2 -3 menit setelah munculnya gejala klinis. Gejala klinis per akut adalah dispnu, cemas, gelisah, ambruk, kejang dan mati (Radostits et al., 2007). Gejala klinis muncul dalam 10 menit sampai satu jam pada keracunan akut. Gejala klinis yang muncul adalah hiperventilasi, penurunan tekanan darah, hipoksemia, eksitasi, konvulsi, koma dan mati. Gejala klinis yang muncul pada kasus moderat adalah kembung, ataksia, dispnu, kejang, dan selanjutnya ambruk (Plumlee, 2004; Nicholson, 2007). Sedangkan gejala keracunan kronis akibat terpapar sianida dapat teramati melalui perkembangan fungsi tiroid, pertumbuhan terhambat dan gangguan syaraf (Kwok, 2008). Keracunan kronis biasanya terjadi pada ternak yang mengonsumsi singkong dalam jangka waktu cukup lama.

Kunci keberhasilan pengobatan adalah diagnosa dan pemberian antidota yang tepat. Pengobatan akan efektif jika riwayat kejadian dan gejala klinis dapat diketahui sejak awal (Whittier, 2011). Uji terhadap sampel pakan yang dikonsumsi dan isi rumen dalam keadaan segar atau beku di laboratorium merupakan uji untuk memperoleh hasil diagnosis secara akurat. Namun demikian penanganan kasus ini biasanya terlambat karena kejadiannya berlangsung cepat sebelum gejala klinis awal teramati (Burrows \& Tyrl, 2001). Pemberian infus $5 \mathrm{~g}$ natrium nitrat dan $15 \mathrm{~g}$ natrium tiosulfat dalam $200 \mathrm{ml}$ air untuk sapi, dan 1 gnatrium nitrat dan $3 \mathrm{~g}$ natrium tiosulfat dalam $50 \mathrm{ml}$ air untuk domba (Kumar, 2003; Radostits et al., 2007). Sedangkan Harris dan Shearer (2003) menganjurkan 3 g natrium nitrat dan $15 \mathrm{~g}$ natrium tiosulfat dalam $200 \mathrm{ml}$ air untuk sapi, sedangkan untuk domba dan kambing adalah $1 \mathrm{~g}$ natrium nitrat dan 2,5 $\mathrm{g}$ natrium tiosulfat dalam $50 \mathrm{ml}$ air. Antidota tersebut diberikan intravena karena jika diberikan peroral tidak akan terabsorbsi (Burrows \& Tyrl, 2001). Antidota lain yang dapat digunakan adalah hidroksokobalamin yang merupakan salah satu bentuk vitamin B12. Hidroksokobalamin kemudian bergabung dengan sianida dan membentuk sianokobalamin. Namun demikian, hidroksokobalamin kurang efektif bila digunakan dalam kasus keracunan $\mathrm{HCN}$ yang berat (Meillier \& Heller, 2015).

\section{KESIMPULAN}

Hijauan sebagai bahan pakan ternak mengandung glikosida sianogenik yang merupakan metabolit sekunder yang dapat menghasilkan HCN yang bersifat toksik pada pemecahan enzimatik. Dari sekian banyak tanaman pakan ternak yang ada di Indonesia, kandungan HCN sangat bervariasi, dari yang rendah sampai tinggi. Namun demikian, kandungan HCN pada pakan hijauan dapat diturunkan dengan berbagai macam metode pemrosesan yang sederhana dan dengan biaya yang tidak mahal serta dapat dilakukan sendiri oleh peternak. Jika sudah terlanjur mengalami keracunan perlu tindakan penanganan khusus.Kunci keberhasilan pengobatan akibat keracunan HCN adalah diagnosa, kecepatan penanganan dan pemberian antidota yang tepat.

\section{DAFTAR PUSTAKA}

Achi, O. \& S. Akomas. 2006. Comporative assessment of fermentation techniques in the processing of fufu, a tradisional fermented cassava product. Pak. J. Nutr. 5:224-229. 
Adekojo, S. A., T. Z. Adama., A. Aremu., \& A. Ijaiya. 2014. Effects of different methods of processing Leucaena leucocephala leaf meal on growth performance and nutrient digestibility of rabbits. International Journal of Agriculture and Forestry 4:380385 DOI:10.5923/j.ijaf.20140405.06

Agbor-Egbe, T. \& I. Lape-Mbome. 2006. The effects of processing techniques in reducing cyanogen levels during the production of some Cameroonian cassava foods. J. Food Composition and Analysis 19(4):354-363. https://dx.doi.org/10.1016/ j.jfca.2005.02.004.

Allen, V.G. \& E. Segarra. 2001. Anti quality components in forage: Overview, significance and economic impart. J. Range Manage 54:49-412.

Andersen, M.D., P.K. Busk, I. Svendsen, \& B.L. Moller. 2000. Cytochromes P-450 from Cassava (Manihot esculenta Crantz) catalyzing the first steps in the biosynthesis of cyanogenic glucosides linamarin and lotaustralin. cloning, functional expression in Pichia pastoris and substrate specificity of the isolated recombinant enzymes. J. Biol. Chem 275(93):1966-1975. DOI: 10.1074/jbc.275.3.1966

Anglani, C. 1998. Sorghum for human foodreview. Plants Human Food for Human Nutrition 52(1):85-95. DOI: 10.1023/A: 1008065519820

Anhwange, B.A. 2008. Chemical composition of Musa sapientum (banana) peels. Journal of Food Technology 6 (6):263-266.

Apata, D.F. \& T.O. Babalola. 2012. The use of cassava, sweet potato and cocoyam, and there by-Products by non-ruminants. International Journal of Food Science and Nutrition Engineering 2:54-62.

Arnold, M., C. Gaskill, S. R.Smith, \& G.D. Lacefield. 2014. Cyanide Poisoning in Ruminants. Agriculture and Natural Resources $\quad 168$. uknowledge.uky.edu/cgi/viewcontent.cgi?a rticle $=1168 \&$ context $=$ anr_reports

(1 Februari, 2019)
Badan Pusat Statistik. 2017. Statistik Tanaman Buah-buahan dan Sayuran Tahunan 2017. https://www.bps.go.id/.../2018/.../statistiktanaman-buah---buahan (9 Februari 2019)

Blood, D.C. \& O.M.Radostits. 1989. Veterinary Medicine: A text book of the diseases of cattle, sheep, pigs, goats and horses.7th Ed.Bailliere Tindall, London.

Borin, K., J.E. Lindberg, \& R.B. Ogle. 2005. Effect of variety and preservation method of cassava leaves on diet digestibility by indigenous and improved pigs. Animal Science 80:319-324.

Bui H.N.P., R.B. Ogle, \& J.K. Lindberg. 2001. Nutritive value of cassava leaves for monogastric animals; Proceedings of workshop on "Use of cassava as animal feed", Khon Kaen University, Thailand http://www.mekarn.org/procKK/phuc.htm. (21 Januari 2019).

Burrows, G.E. \& R.J. Tyrl. 2001. Toxic Plants of North America Ames, Iowa: Iowa State: 1300-1342.

Chandrika U.G., W.S. Wedage, S.M.D. N. Wickramasinghe, \& W.S. Fernando. 2006. Hypoglycaemic action of the flavanoid fraction of Artocarpus heterophyllus Leaf. Afr. J. Trad. CAM 3(2):42-50.

Cardoso, A.R., E. Mirione, M. Ernesto, F. Massaza, J. Cliff, M.R. Haque, \& H.J. Bradbury. 2005. Processing of cassava roots to remove cyanogens. J. Food Comp. Anal 18(5):451-460. https://doi.org/ 10.1016/j.jfca.2004.04.002

Carlsson, M.P. \& B. Anderson. 2013. Cyanogenic glycosides. http://extension.unl.edu /publications. (21 Desember 2018).

Chaouali, N., I. Gana, A. Dorra, F. Khelifi, A. Nouioui, W. Masri, I. Belwaer, H. Hayet Ghorbel, \& A. Hedhili. 2013. Potential toxic levels of cyanide in almonds (Prunus amygdalus), apricot kernels (Prunus armeniaca), and Almond Syrup. ISRN Toxicology 13:1-6.

Departemen Perindustrian. 1999. Departemen Perindustrian dan Perdagangan Republik 
Indonesia, Badan Pengawas Perdagangan Berjangka Komoditi, Peristilahan Dalam Perdagangan Berjangka Komoditi. Jakarta Maret 1999.

El-Sharkawy, M.A. 2004. Cassava biology and physiology. Plant Molecular Biology 56 (4):481-501. DOI: http://dx.doi.org/10.1007 /s11103-005-2270-7.

Enneking, D. \& M. Wink. 2000. Towards The Eliminationof Anti-Nutritional Factors in Grain Legume. Knight (ed.), Linking Research and Marketing Opportunities for Pulses in the $21^{\text {st }}$ Century, Kluwer Academic Publishers :671-683.

Etuk, E.B., N.J. Okeudo, B.O. Esonu, \& A.B.I. Udedibie. 2012. antinutritional factors in sorghum: chemistry, mode of action and effects on livestock and poultry. J. of Anim. Feed Res. 2(2):113-119.

Ersam, T. 2001. Senyawa Kimia Makromolekul beberapa Tumbuhan Artocarpus Hutan Tropika Sumatera Barat. Disertasi. Institut Teknologi Bandung. Bandung.

Fardet, A. 2010. New hypotheses for the healthprotective mechanisms of whole-grain cereals: What is beyond fibre? Nutr. Res. Rev. 23(1):65-134. DOI: http://dx.doi.org/ $10.1017 /$ S0954422410000041.

Fasuyi, A.O. 2005. Nutrient Composition and Processing Effects on Cassava (Manihot esculenta, Crantz) Leave Antinutrients. Pakistan Journal of Nutrition 4:37-42. DOI: http://dx.doi.org/10.3923/pjn.2005.37.42.

Francisco, I.A. \& M.H.P. Pinotti. 2000. Cyanogenic glycosides in plants. Brazilian Archives of Biology and Technology 43: 487-492. DOI: http://dx.doi.org/10.1590/ S1516- 89132000000500007.

Ganjewala, D., S. Kumar, S.A. Devi, \& K. Ambika. 2010. Advances in cyanogenic glycosides biosynthesis and analyses in plants: A review. Acta Biologica Szegediensis 54(1): 1-14.

Hang, D.T. \& T.R. Preston. 2005. The effects of simple processing methods of cassava leaves on $\mathrm{HCN}$ content and intake by growing pigs. Livestock Research for Rural Development 17:9.

Haque, M.R. \& J.H. Bradbury. 2002. Total cyanide determination of plants and foods using the picrate and acid hydrolysis methods. Food Chemistry 77(1):107-114. DOI: https://dx.doi.org/10.1016/S03088146(01)00313-2.

Harris, B. \& J.K. Shearer. 2003. Nitrate, prussic acid $(\mathrm{HCN})$ and grass tetany problems in cattle feeding, Technical Document, DS6, Animal Science Department, Florida Cooperative Extension Service, Institute of Food and Agricultural Sciences, University of Florida. http://edis.ifas.ufl.edu.

Hlaing, A., K. Naing, S.S. Myint, \& Y.M. Aung. 2011. Study on reaction between ninhydrine and cyanide and its analytical applications. University Research Journal 4(3):283-300.

Kavana, P.Y., K. Mtunda, A. Abass, \& V. Rweyendera. 2005. Promotion of cassava leaf silage utilization for smallholder dairy production in Eastern coast of Tanzania. Livestock Research for Rural Development 17(14):1-12.

Kobawila, S.C., D. Louembe, S. Keleke, J. Hounhouigan, \& C. Gamba. 2005. Reduction of the cyanide content during fermentation of cassava roots and leaves to produce bikedi and ntoba mbodi, two food products from Congo. African Journal of Biotechnology 4(7):689-696. DOI: 10.5897 /AJB2005.000-3128.

Kumar, R. 2003. Anti-nutritive factors, the potential risksof toxicity and methods to alleviate them. http:// www.fao.org/ DOCREP/003/T0632E/T0632E10.htm. (29 Desember 2018).

Kumoro, A.C., D.S. Retnowati, \& C.S. Budiyati. 2011. Removal of cyanides from gadung (Dioscorea hispida Dennst.) tuber chips using leaching and steaming techniques. Journal of Applied Sciences Research 7:2140-2146.

Kwok. 2008. Cyanide Poisoning and Cassava. Centre for Food Safety. http://www.cfs. 
gov.hklenglishlmultimedia/multimedia_pb/ multimedia_pub_fsf_19_01.html (29 Januari 2019).

Lambri, M., M.D. Fumi, A. Roda, \& D.F.D. Marco. 2013. Improved processing methods to reduce the total cyanide content of cassava roots from Burundi. African Journal Biotechnol 12:2685-2691 DOI: http://dx.doi.org/ 10.5897/ AJB2012.2989.

Leder, I. 2004. Sorghum and Millets. in Cultivated Plants, Primarily as Food Sources. in Encyclopedia of Life Support Systems (EOLSS), Developed under the Auspices of the UNESCO. Eolss Publishers. Oxford. http:/www.eolss.net. :1-18. (1 Juni 2013).

McKenzie, R.A. 2002. Toxicology for Australian veterinarians (electronic resource). Ashgrove, Queensland:130-147.

Meillier, A., \& C. Heller. 2015. Acute cyanide poisoning: hydroxocobalamin and sodium thiosulfate treatments with two outcomes following one exposure event. Case Reports in Medicine 2015:1-4. DOI: http://dx.doi.org/10.1155/2015/217951.

Montagnac, J.A., R.D. Christopher, \& S.A. Tanumihardjo. 2009. Processing techniques to reduce toxicity and antinutrients of cassava for use as a staple food. Comprehensive Reviews in Food Science and Food Safety 8(1):17-27. DOI: https://dx.doi.org/10.1111/j.1541-4337. 2008.00064.

Moller, B.L. 2010. Functional diversifications of cyanogenic glucosides. Current Opinion in Plant Biology 13(3):338-347. DOI: https://doi.org/10.1016/j.pbi.2010.01.009.

Nicholson, S.S. 2007. Cyanogenic plants. In: Veterinary Toxicology: Basic and Clinical Principles. Editor Gupta, R.C. Academic Press. USA. pp 873-875.

Chanchay, N. \& N. Poosaran. 2009. The reduction of mimosine and tannin contents in leaves of Leucaena leucocephala. Asian J. of Food and Agro-Industry S137-S144.
Oduguwa, O.O. \& A.O. Fafiolu. 2004. Utilization of Malted Sorghum Sprouts in the Diets of Starting Chicken. Proceedings of $9^{\text {th }}$ Annual Conference Animal Science Association of Nigeria. Ebonyi State University, Abakiliki, September 13-16. pp. 67-69.

Oluremi, I.O.A. \& A. Nwosu, 2002. The effect of soaked cassava peel on weanling rabbits. $\mathbf{J}$ Food Technol Afr 7(1):12-15. DOI: http://dx.doi.org/10.4314/jfta.v7i1.19311.

Onyeonagu, C. C., P. N. Obute, \& S. M. Eze. 2013. Seasonal variation in the antinutrient and mineral components of some forage legumes and grasses. Afr. J. Biotechnol 12(2):142-149. DOI: http:// dx.doi.org /10.5897/AJB11.1359.

Onyeonagu, C.C. \& C.C. Ukwueze. 2012. Antinutrient components of guinea grass (Panicum maximum) under different nitrogen fertilizer application rates and cutting management. Afr. J. Biotechnol 11(9): 2236-2240. DOI: http://dx.doi.org/ 10.5897/ AJB11.748.

Pandey, R.K., D. Kumar, \& K.M. Jadhav. 2011. Assessment of determinants for reducing HCN content in sorghum used for ruminant in Gujarat, India. Livestock Research for Rural Development 23(3): article 66. http://www.lrrd.org//rrd23/3/pand23066.ht $\mathrm{m}$.

Phengvichith, V. \& I. Ledin. 2007. Effect of feeding different levels of wilted cassava foliage (Manihot esculenta, Crantz) on the performance of growing goats. Small Ruminant Research 71(1-3):109-116. DOI: http://dx.doi.org/10.1016/j.smallrumres.20 06.05.009

Pickrell, J.A., F.W. Oehme, \& S.R. Hickman. 1991. Drought increases forage nitrate andcyanide. Veterinary and Human Toxicology 33(3):247-251.

Plumlee, K.H. 2004. Plants: cyanogenic glycoside. In: Clinical Veterinary Toxicology, Mosby Inc., Missouri. pp 391392. 
Poulton, J.E. 1990. Cyanogenesis in Plants. Plant Physio 194(2):401-405. PMCID:PMC 1077245.

Prasad, S. \& M. S. Dhanya. 2011. Determination and detoxification of cyanide content in sorghum for ethanol production using Saccharomyces cerevisiae strain. Journal of Metabolomics and Systems Biology 2(1):10-14.

Prodanov, M., I. Sierra, \& C. Vidal-Valverde. 2004. Influence of soaking and cooking on the thiamin, riboflavin and niacin contents of legumes. Food Chemistry 84:271-277.

Putra, I.N.K. 2009. Efektifitas berbagai cara pemasakan terhadap penurunan kandungan asam sianida berbagai jenis rebung bamboo. Agrotekno 15:40-42.

Radostits, O.M., C.C. Gay, K.W. Hinchcliff, \& P.D. Constable. 2007. Veterinary Medicine: A Textbook of the diseases of cattle, sheep, goats, pigs, and horses. $10^{\text {th }}$ Edition. Saunders Elsevier. London. pp 1852-1855.

Simeonova, F.P. \& L. Fishbein. 2004. Hydrogen cyanide and cyanides: Human health aspects. Concise International Chemical Assessment Document 61. World Health Organization. Geneva.

Simili, F.F., M.C. Pereira Lima, M.I. de Medeiros, C.C. de Paz, A.C. Ruggieri, \& R.A. Reis. 2013. Hydrocyanic acid content and growth rate of sorghum $x$ Sudan grass hybrid during fall. Ciênc. Agrotec 37(4): 299-305. DOI: http://dx.doi.org/10.1590/ S1413-70542013000400002.

Sirappa, M.P. 2003. Prospek pengembangan sorgum di Indonesia sebagai alternative komoditas untuk pangan, pakan dan industri. Jurnal Litbang Pertanian 22(4):133-140.

Siritunga, D., D. Arias-Garson, W. White, \& R.T. Sayre. 2004. Over-expression of hydroxynitrile lyase in transgenic cassava roots accelerates cyanogenesis and food detoxification. Plant Biotech. J2:37-43. DOI: http://dx.doi.org/10.1046/j.14677652.2003.00047.x
Soetan, K.O. 2008. Pharmacological and other beneficial effects of antinutritional factors in plants. -A Review. Afr. J. Biotechnol 7:4713-4721.

Sokerya, S., P. Try, P.J. Waller, \& J. Höglund. 2009. The effect of long-term feeding of fresh and ensiled cassava (Manihot esculenta, Crantz) foliage on gastrointestinal nematode infections in goats. Tropical Animal Health Production 41:251-58.

Sousa, A.B., H.Manzano, B. Soto-Blanco, \& S. L. Górniak. 2003. Toxicokinetics of cyanide in rats, pigs and goats after oral dosing with potassium cyanide. Archives of Toxicology 77(6):330-334. DOI: http://dx.doi.org/10.1007/s00204-0030446-y.

Stoltenow, C. \& G.Lardy. 2012. Cyanic Poisoning. https://www.ag.ndsu.edu/pubs/ ansci/livestoc/v1150:1-4. (25 Des 2018).

Ugwu, F.M., \& N.A. Oranye. 2006. Effects of some processing methods on the toxic components of african breadfruit (Treculia africana). African Journal of Biotechnology 5:2329-2333.

USDA. 2001. Phytochemical and Ethnobotanical Database. Treating Livestock Medical Plant or Toxis. Caria papaya. http://www.probe.nalusda.gov:8300/ogibin /browse/phytochemdb. (17 Juli, 2013).

Vetter, J. 2000. Plant cyanogenic glycosides. Toxicon38(1):11-36.DOI: https://dx.doi.org/ 10.1016/S0041-0101(99)00128-2.

Whittier, J.C. 2011. Prussic acid poisoning. Colorado State University Extension Publication. http://extension.colostate.edu/ topic/prussic-acid-poisoning-1-612:1-2. (27 Januari 2019).

Yildiz, K., B. Dokuzeylul, R. Gonul \& M.O.R. Erman. 2017. Cyanide Poisoning in Cattle. Journal of Dairy \& Veterinary Sciences 1: 1-4. DOI: http://dx.doi.org/10.19080/JDVS. 2017.01.555567.

Yuningsih, 2007. Kasus keracunan pada hewan di Indonesia dari tahun 1992-2005. Seminar 
Nasional Teknologi Peternakan dan Veteriner, 21-22 Agustus 2007. Pusat Penelitian dan Pengembangan Peternakan, Bogor.

Yuningsih. 2012. Keracunan sianida pada hewan dan upaya pencegahannya. Jurnal Litbang Pertanian 31(1):21-25. DOI: http://dx.doi.org/ 10.21082/jp3.v31n1.2012.p\%25p
Zagrobelny, M., S. Bak, A.V. Rasmussen, B. Jørgensen, C.M.Naumann, \& L.B. Møller. 2004. Cyanogenic glucosides and plantinsect interactions. Phytochemistry 65(3):293-306. DOI: http://dx.doi.org/ 10.1002/chin.200422257. 